\title{
PODATEK ROLNY JAKO ŹRÓDŁO DOCHODÓW WŁASNYCH GMIN WIEJSKICH W POLSCE
}

\author{
Agnieszka Kozera \\ Katedra Finansów i Rachunkowości Uniwersytetu Przyrodniczego w Poznaniu \\ Kierownik katedry: prof. dr hab. Feliks Wysocki
}

\begin{abstract}
Słowa kluczowe: podatek rolny, podatki lokalne, dochody własne gmin, skutki władztwa podatkowego, gminy wiejskie, gminy miejskie, gminy miejsko-wiejskie

Key words: agricultural tax, local taxes, own income, effects of the power of tax, rural communes

S y n o p s i s. Celem głównym artykułu jest przedstawienie znaczenia podatku rolnego jako źródła dochodów własnych gmin wiejskich w Polsce w latach 2004-2015. Aby określić znaczenie fiskalne omawianego podatku, analizie poddano kształtowanie się wysokości i udziału dochodów z podatku rolnego w dochodach własnych gmin wiejskich na tle pozostałych typów administracyjnych oraz wysokość utraconych z jego tytułu dochodów. Przeprowadzone badania wykazały, że podatek rolny największą rolę jako źródło dochodów własnych odgrywa w gospodarce budżetowej gmin wiejskich, chociaż rola fiskalna tego podatku w tych podmiotach sektora samorządowego jest coraz mniejsza. Nieefektywny z punktu widzenia samodzielności finansowej gmin system opodatkowania rolnictwa podatkiem rolnym, którego konstrukcja w bardzo niewielkim stopniu powiązana jest z rzeczywistą wielkością produkcji i dochodów w rolnictwie, przekłada się na niski poziom własnego potencjału dochodowego gmin wiejskich.
\end{abstract}

\section{WSTĘP}

Gminy jako podstawowe jednostki samorządu terytorialnego (JST) w celu realizacji przypisanych im zadań wyposażone zostały w źródła tzw. dochodów własnych. Zalicza się do nich m.in. te, w wypadku których występuje władztwo podatkowe, posiadanie własności określonych źródeł dochodów albo uprawnień do wprowadzania i kształtowania określonych dochodów. Jak podaje m.in. Maria Jastrzębska [Jastrzębska 2012], dochody własne pochodzą ze źródeł znajdujących się na terenie JST, co stwarza władzom samorządowym możliwość oddziaływania na ich wydajność. Należy jednak podkreślić, że w polskim prawodawstwie, zgodnie z Konstytucją RP [Dz.U. 1997.78.483, art. 167, ust. 2], dochodami własnymi są te, które nie stanowią subwencji ogólnej i dotacji celowych z budżetu państwa, a więc do dochodów własnych zaliczane są również dochody z tytułu udziałów we wpływach z podatków dochodowych stanowiących dochód budżetu państwa. Dochody własne gmin pochodzą więc z pięciu podstawowych źródeł, tj. z podatków lokalnych, opłat lokalnych, udziałów w podatkach państwowych (PIT i CIT), z majątku komunalnego i pozostałych źródeł. Ich wysokość i udział w dochodach ogółem gmin ma duże znaczenie dla możliwości zaspokojenia potrzeb ich mieszkańców, a także dla stabil- 
nego rozwoju lokalnego. Jednocześnie analiza własnego potencjału dochodowego gmin pozwala określić długookresową zdolność samorządów do finansowania realizowanych przez nie zadań [Lubińska i in. 2007].

Źródłem dochodów własnych gmin, mającym znaczny wpływ na ich funkcjonowanie są dochody z tytułu podatków lokalnych. Podmioty te mają wyłączność czerpania dochodów $\mathrm{z}$ ich tytułu, a także wyposażone zostały w tzw. władztwo podatkowe, co oznacza prawo podejmowania decyzji w sprawach ustalania ich stawek oraz kierunków rozdysponowania. Dochody z tytułu podatków lokalnych stanowią jedną trzecią dochodów własnych gmin ogółem w Polsce, natomiast prawie 40\% w gminach wiejskich [Bank Danych Lokalnych, dostęp: 10.01.2017]. Wśród grupy podatków lokalnych wyróżnia się m.in. podatki od nieruchomości, rolny, leśny, od środków transportowych, od czynności cywilnoprawnych oraz od spadków i darowizn. Ze względu na znaczny udział użytków rolnych w powierzchni ogółem gmin wiejskich (przeciętnie 70\%), w gospodarce budżetowej tych podmiotów szczególne znaczenie odgrywa podatek rolny. Ze względu na to, że jest on płacony niezależnie od poziomu uzyskiwanych przychodów z gospodarstwa rolnego klasyfikowany jest on najczęściej do grupy podatków majątkowych [por. Chmielewska 2009]. Podstawowe zasady opodatkowania rolnictwa podatkiem rolnym zostały opracowane w 1984 roku i obowiązują w praktycznie niezmienionej postaci od 1985 roku.

Podatek rolny w polskim systemie podatkowym, jak zauważa m.in. Marzena Chmielewska [Chmielewska 2009], jest głównym obciążeniem podatkowym ponoszonym przez gospodarstwa rolne i odprowadzanym do budżetów gmin, na których terenie położone są grunty podlegające opodatkowaniu. Specyfiką polskich rozwiązań podatkowych, podobnie jak w wielu państwach Unii Europejskiej (UE), jest uprzywilejowane traktowanie rolnictwa. Wyrazem tego jest m.in. wyłączenie dochodów rolniczych z opodatkowania podatkiem dochodowym (należącym do grupy podatków państwowych) [Przygodzka 2016]. Preferencje dla rolnictwa nie ograniczają się tylko do podatku dochodowego. Niewielką rolę w systemie obciążeń podatkowych rolnictwa odgrywa m.in. podatek od nieruchomości w wyniku stosowania zwolnień budynków rolnych i ich części położonych na gruntach gospodarstw rolnych i służących wyłącznie działalności rolniczej z tego podatku. Rolnictwo korzysta również ze zwolnienia z podatku od środków transportowych, jak również z podatku od spadków i darowizn. Należy także podkreślić, że wydolność fiskalna podatku rolnego, ze względu na brak powiązania stawek tego podatku z rzeczywistą wielkością produkcji i wynikami ekonomicznymi gospodarstw rolnych, jak zauważył m.in. Lech Goraj z zespołem [Goraj i in. 2014, s. 25], jest bardzo ograniczona. W rezultacie gminy wiejskie o typowo rolniczym charakterze wyróżniają się znacznie niższym poziomem samodzielności finansowej [por. Kozera, Wysocki 2015], który jest warunkiem rozwoju lokalnego.

Celem artykułu jest przedstawienie znaczenia podatku rolnego jako źródła dochodów własnych gmin wiejskich w Polsce w latach 2004-2015. Analizie poddano kształtowanie się wysokości i udziału dochodów z podatku rolnego w dochodach własnych gmin wiejskich na tle pozostałych typów administracyjnych, a także wysokość utraconych z tego tytułu dochodów na skutek stosowania przez gminy tzw. władztwa podatkowego. Podstawę informacyjną przeprowadzonych badań stanowiły dane pochodzące z GUS [Bank Danych Lokalnych, Roczne wskaźniki makroekonomiczne] oraz Ministerstwa Finansów [Budżety...]. Do badań wykorzystano podstawowe metody statystyki opisowej. 


\section{CHARAKTERYSTYKA PODATKU ROLNEGO W POLSCE}

W polskim systemie opodatkowania rolnictwa głównym obciążeniem fiskalnym jest podatek rolny, który dotyczy bezpośrednio gospodarstw rolnych. Z badań przeprowadzonych przez Magdalenę Mądrą [Mądra 2009] wynika bowiem, że stanowi on ponad 80\% ogółu obciążeń fiskalnych w gospodarstwach rolnych. Jak zauważyła Renata Przygodzka [Przygodzka 2016], specyfiką polskich rozwiązań podatkowych jest uprzywilejowane traktowanie rolnictwa. Przede wszystkim dochody rolnicze wyłączone są z opodatkowania podatkiem dochodowym, co wynika z artykułu 2 ust. 1 ustawy o podatku dochodowym od osób fizycznych ${ }^{1}$. Oznacza to, że niezależnie od osiąganych wyników ekonomicznych gospodarstw rolnych ich dochody z prowadzonej działalności rolniczej nie podlegają opodatkowaniu. W rezultacie wpływy do budżetów gmin wiejskich o charakterze typowo rolniczym ze źródeł dochodów własnych w przeliczeniu na mieszkańca są dużo niższe w porównaniu do pozostałych typów administracyjnych gmin (podatków lokalnych i podatków dochodowych stanowiących dochód budżetu państwa). Tym samym mają mniejszą samodzielność finansową [por. Kozera, Wysocki 2015] oraz gminy te, jak podkreśla R. Przygodzka [Przygodzka 2014b], mają poważne problemy z pozyskiwaniem środków zewnętrznych o charakterze bezzwrotnym (przede wszystkim środków z UE) oraz zwrotnym (kredyty, pożyczki). Podatek rolny ma charakter majątkowy, co oznacza, że obowiązek jego zapłaty wiąże się z samym faktem władania gruntem, a nie z osiąganiem korzyści z posiadanej własności.

Podstawą naliczania i poboru podatku rolnego jest Ustawa z dnia 15 listopada 1984 roku o podatku rolnym. Według niej podatnikami podatku rolnego są osoby fizyczne, osoby prawne, jednostki organizacyjne, w tym spółki bez osobowości prawnej, a będące właścicielami albo samoistnymi posiadaczami gruntów, użytkownikami wieczystymi gruntów lub posiadaczami gruntów stanowiących własność Skarbu Państwa lub jednostki samorządu terytorialnego ${ }^{2}$ [Dz.U.2016.617, art. 3].

Przedmiotem opodatkowania podatkiem rolnym są grunty sklasyfikowane w ewidencji gruntów i budynków jako użytki rolne lub grunty zadrzewione lub zakrzewione na użytkach rolnych, z wyjątkiem gruntów zajętych na prowadzenie działalności gospodarczej innej niż działalność rolnicza. Podstawą wymiaru podatku rolnego jest ekonomiczna wartość użytkowa gruntów tworzących gospodarstwo rolne, która jest ściśle uzależniona od rodzaju i klasy użytków rolnych podlegających opodatkowaniu, a także od ich położenia w danym okręgu podatkowym [Chmielewska 2009]. W ramach konstrukcji podatku rolnego wyróżniono cztery okręgi podatkowe, czyli zróżnicowaną stawkę obciążenia fiskalnego z uwagi na warunki ekonomiczne i przyrodniczo-klimatyczne. Najwyższy przelicznik powierzchni użytków rolnych, czyli najwyższą ekonomiczną wartość użytkową gruntów przewidziano dla gruntów ornych I klasy bonitacyjnej w I okręgu podatkowym, który wynosi 1,95 , natomiast najniższy m.in. dla gruntów ornych VI klasy bonitacyjnej w IV okręgu podatkowym, który stanowi 0,05 [Dz.U.2016.617, art. 4].

Stawka podatku rolnego jest wyznaczana na podstawie średniej ceny skupu żyta. Do 2013 roku ustalana była na podstawie pierwszych 3 kwartałów roku poprzedzającego rok

Od 1 stycznia 1992 roku podatkiem dochodowym objęte są działy specjalne produkcji rolnej.

2 Jeżeli posiadanie wynika z umowy zawartej z właścicielem, z Agencją Nieruchomości Rolnych lub z innego tytułu prawnego albo jest bez tytułu prawnego, z wyjątkiem gruntów wchodzących w skład Zasobu Własności Rolnej Skarbu Państwa lub będących w zarządzie Lasów Państwowych, to podatnikami są jednostki organizacyjne, czyli odpowiednio Agencja Nieruchomości Rolnych i Lasy Państwowe [Kiełczyńska-Kiełbasa 2015]. 
podatkowy, natomiast od 2014 roku z 11 kwartałów poprzedzających kwartał poprzedzający rok podatkowy. Średnią cenę ogłasza corocznie Prezes GUS. W przypadku gospodarstw rolnych podatek rolny wynosi równowartość pieniężną 2,5 q żyta za każdy hektar przeliczeniowy, natomiast dla pozostałych użytków rolnych 5 q żyta za każdy ha przeliczeniowy [Dz.U.2016.617, art. 6]. W literaturze wielokrotnie podkreśla się, że o ile w latach 80 . minionego wieku powiązanie obciążeń podatkowych z ceną żyta mogło znaleźć uzasadnienie, obecnie trudno znaleźć argumenty przemawiające za takim rozwiązaniem [por. Goraj i in. 2014, Przygodzka 2016].

Wysokość wpływów z tytułu podatku rolnego do budżetów gmin zależy nie tylko od kształtowania się stawki tego podatku, lecz także od prowadzonej przez gminy polityki podatkowej. Gminy mają bowiem możliwość ustalania stawki niższej niż ta ogłoszona przez Prezesa GUS. Kształtowanie się przeciętnej wysokości średniej ceny skupu żyta, stanowiącej podstawę obliczenia stawki podatku rolnego w latach 2004-2015, a także wysokość górnych stawek podatkowych dla gruntów wchodzących w zakres gospodarstwa rolnego i pozostałych gruntów rolnych przedstawiono w tabeli 1 . W 2015 roku w relacji do 2004 roku stawka podatku rolnego uległa zwiększeniu na skutek zmiany średniej ceny skupu żyta. Najwyższe stawki podatku rolnego zanotowano w latach 2012 i 2013, z kolei najniższą w 2006 roku. Do 2012 roku można zauważyć, że wysokość górnych stawek podatkowych dla podatku rolnego była silnie zróżnicowana. Wydłużony okres obliczania średniej ceny skupu żyta (od 3 do 11 kwartałów) wprowadzony od roku podatkowego 2014, niewątpliwie przyczyni się do wyższej stabilności dochodów z podatku rolnego uzyskiwanych przez gminy. Pozwoli to ustabilizować i urealnić cenę skupu żyta w dłuższym okresie i uniezależnić stawkę podatku rolnego od chwilowych wahań cen na rynku zbóż.

Podatek rolny podlega wielu zwolnieniom i ulgom zdefiniowanym w ustawie o podatku rolnym z 1984 roku. Przykładem ulgi w tym podatku jest ulga inwestycyjna (jeżeli wydatki te nie zostały sfinansowane w całości lub w części z udziałem środków publicznych) z tytułu wydatków poniesionych na budowę lub modernizację budynków inwentarskich służących do chowu, hodowli i utrzymania 
zwierząt gospodarskich oraz obiektów służących ochronie środowiska, a także zakup i zainstalowanie m.in. deszczowni i urządzeń melioracyjnych. Na wniosek podatnika w razie wystąpienia klęski żywiołowej, która spowodowała istotne szkody w budynkach, ziemiopłodach, inwentarzu żywym lub martwym albo drzewostanie, przyznaje się ulgi w podatku rolnym przez zaniechanie jego ustalania albo poboru w całości lub w części, w wysokości zależnej od rozmiarów strat spowodowanych klęską w gospodarstwie rolnym [Kiełczyńska-Kiełbasa 2015]. W określonym zakresie rady gmin mają także uprawnienie do kształtowania podstawy opodatkowania poprzez przekwalifikowanie poszczególnych użytków rolnych [Dz.U.2016.617, art. 5].

\section{WYNIKI BADAŃ EMPIRYCZNYCH - PODATEK ROLNY W BUDŻETACH GMIN WIEJSKICH NA TLE POZOSTAŁYCH TYPÓW ADMINISTRACYJNYCH}

W tabeli 2. przedstawiono wielkość wpływów do budżetów gmin w układzie typów administracyjnych z tytułu podatku rolnego w latach 2004-2015. W 2004 roku wpływy do budżetów gmin ogółem z tego podatku stanowiły 921,8 mln zł, z kolei w 2015 roku $1593,0 \mathrm{mln}$ zł, czyli o prawie $73 \%$ więcej w ujęciu nominalnym. Zdecydowanie najwyższe dochody $\mathrm{z}$ podatku rolnego $\mathrm{w}$ całym analizowanym okresie zaobserwowano $\mathrm{w}$ gminach wiejskich, które zgromadziły ponad $60 \%$ ogółu dochodów z tytułu podatku rolnego wszystkich gmin w Polsce. Najmniejsze znaczenie fiskalne podatek ten odgrywał w przypadku gmin miejskich, w których wpływy z podatku rolnego w 2015 roku stanowiły co najwyżej 4\% ogółu dochodów z tego tytułu. Należy jednak zauważyć, że na tle przemian społeczno-gospodarczych zachodzących w funkcjonowaniu gospodarstw rolnych w warunkach integracji europejskiej, dochody gmin z tytułu podatku rolnego w ujęciu realnym wzrosły zaledwie o jedną trzecią, podczas gdy poziom dochodów własnych ogółem tych podmiotów wzrósł dwukrotnie ${ }^{3}$.

O znaczeniu podatku rolnego jako źródła dochodów własnych gmin świadczy ich poziom w zł per capita i udział $\mathrm{w}$ dochodach własnych oraz $\mathrm{w}$ dochodach $\mathrm{z}$ tytułu podatków lokalnych (tab. 2.). Zdecydowanie najwyższy poziom dochodów z podatku rolnego wyróżnia gminy wiejskie, w których w 2015 roku stanowiły one ponad 91 zł per capita, względem 41,4 zł per capita dla ogółu gmin w Polsce. Przeciętne wpływy z podatku rolnego w relacji do dochodów własnych wszystkich gmin stanowiły relatywnie niewielką część, tj. najwyższy udział w 2004 roku - 2,4\%, natomiast najniższy w latach 2010 i $2011-1,5 \%$ ogółu dochodów własnych. Zdecydowanie wyższy udział wpływów z podatku rolnego w dochodach własnych występuje w grupie gmin wiejskich. Najwyższy ich udział zaobserwowano w 2004 roku - 9,1\%, natomiast najniższy w 2015 roku - 6,1\%. Należy jednak zauważyć, że podatek rolny odgrywa w tych podmiotach relatywnie niewielką rolę i jego znacznie jako źródła dochodów własnych sukcesywnie maleje.

Analizując strukturę dochodów własnych z tytułu podatków lokalnych, można zauważyć, że podatek rolny odgrywa największą rolę w gminach wiejskich. W podmiotach tych w całym analizowanym okresie stanowił on przeciętnie około $18 \%$ ogółu dochodów z podatków lokalnych, podczas gdy w gminach ogółem tylko niespełna 7\% (tab. 2.). W

\footnotetext{
Nominalne dochody własne w przeliczeniu na mieszkańca gmin wiejskich wzrosły z poziomu 604,9 zł w 2004 roku do 1501,4 zł w 2015 roku, czyli ponaddwuipółkrotnie. Z kolei według cen stałych z 2004 roku, z poziomu 604,9 zł w 2004 roku do 1186,9 zł per capita w 2015 roku, czyli prawie dwukrotnie [Bank Danych Lokalnych, Roczne wskaźniki makroekonomiczne, dostęp: 16.01.2017].
} 


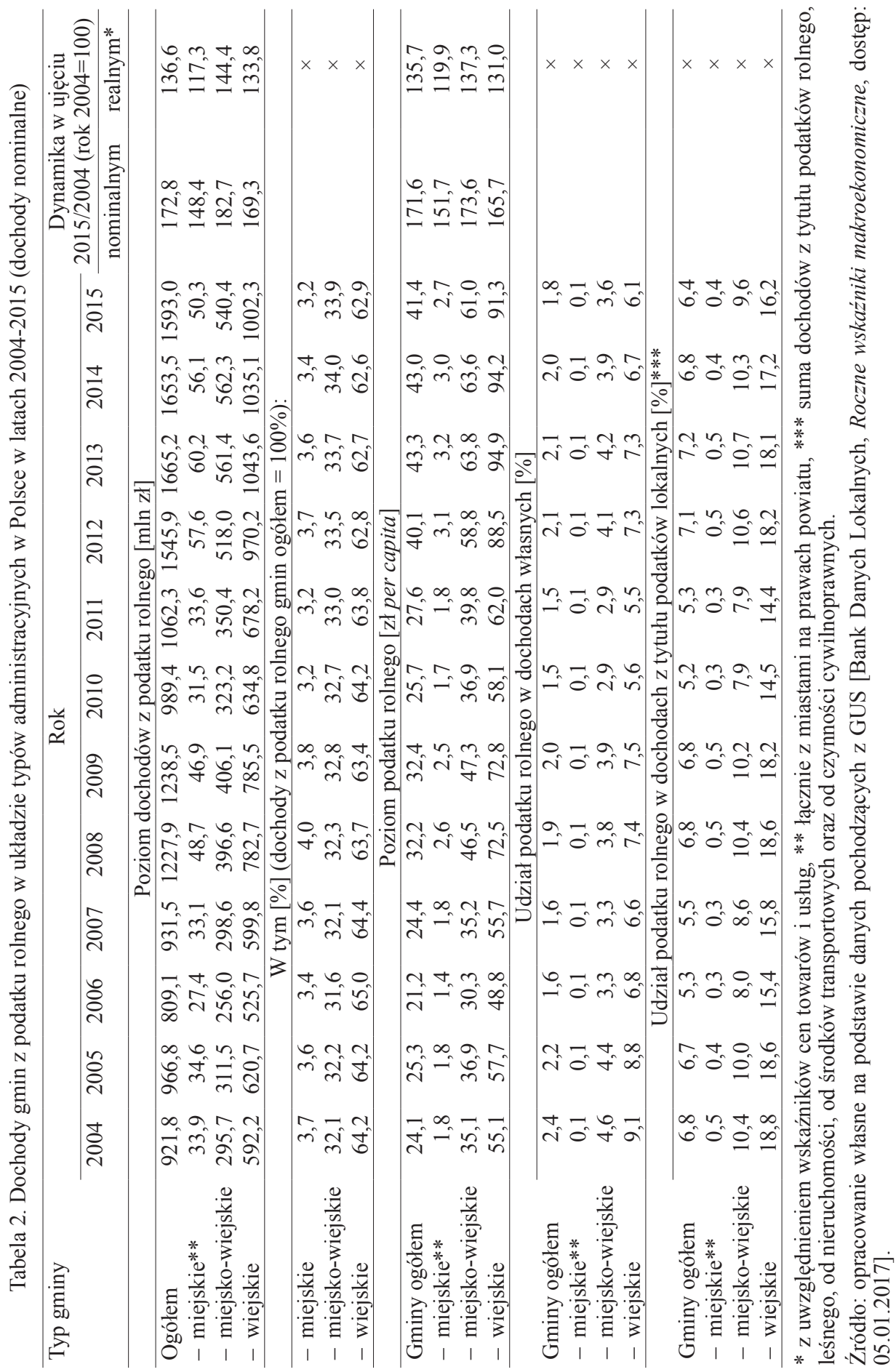


latach 2004-2015 nie stwierdzono jednoznacznej tendencji w zakresie kształtowania się udziału podatku rolnego w dochodach własnych gmin wiejskich i w dochodach z podatków lokalnych. Przyczyną tej sytuacji mogła być niestabilność cen żyta w badanych latach i prowadzona przez samorządy gminne polityka podatkowa w zakresie stosowania niższych stawek podatkowych oraz ulg i zwolnień.

Gminy mają władztwo podatkowe, dzięki któremu kształtują obciążenia podatkowe, a nie stanowią podatków. W przypadku podatku rolnego rada gminy może obniżyć cenę skupu żyta, która jest podstawą naliczania obciążeń podatkowych. Do zakresu kompetencji rady gminy należy również stosowanie, zgodnie z przepisami ustawy o podatku rolnym, zwolnień i ulg podatkowych w wyniku decyzji urzędu albo na wniosek podatnika (np. w sytuacji wystąpienia klęski żywiołowej). Uprawnienia przyznane radom gmin w zakresie władztwa podatkowego są przez nie systematycznie stosowane. W odniesieniu do podatku rolnego analiza uchwał podatkowych gmin wykazuje, że znaczna część gmin korzysta głównie z uprawnień dotyczących obniżania cen żyta. Działania te, zwłaszcza stosowanie niższych stawek podatkowych, wpływają na znaczne zmniejszenie dochodów własnych gmin, a więc na niższy poziom ich samodzielności finansowej. R. Przygodzka skutki stosowania władztwa podatkowego określa jako tzw. utracone dochody [Przygodzka 2014a].

Zdecydowanie najwyższy poziom utraconych dochodów w wyniku stosowania władztwa podatkowego, nie tylko w zakresie podatku rolnego, jak wynika m.in. z badań przeprowadzonych przez R. Przygodzką [Przygodzka 2014b] i Beatę Filipiak [Filipiak 2016], odnotowano w gminach wiejskich. Takie konsekwencje stosowania władztwa podatkowego $\mathrm{w}$ zakresie podatku rolnego $\mathrm{w}$ gminach wiejskich wynikają $\mathrm{z}$ obniżenia górnych stawek podatkowych (tab. 3.). Z tego tytułu gminy wiejskie w 2015 roku utraciły prawie 207 mln zł. Utracone dochody były znacznie niższe z tytułu pozostałych rodzajów władztwa podatkowego, a zdecydowanie najniższe w wyniku stosowania ulg i zwolnień $(2,8 \mathrm{mln}$ zł) oraz rozłożenia terminu płatności na raty lub jego odroczenia $(2,3 \mathrm{mln}$ zł). Niemniej jednak, w samym 2015 roku skutki władztwa podatkowego w zakresie podatku rolnego stanowiły łącznie ponad jedną piątą dochodów z tytułu podatku rolnego gmin wiejskich, tj. podmiotów o najniższym poziome własnego potencjału dochodowego.

Tabela 3. Skutki podatkowe władztwa podatkowego gmin w układzie typów administracyjnych w zakresie podatku rolnego w 2015 roku

\begin{tabular}{|c|c|c|c|c|c|c|}
\hline \multirow[t]{2}{*}{ Typ gminy } & \multicolumn{4}{|c|}{ Rodzaj władztwa podatkowego [mln zł] } & \multirow{2}{*}{$\begin{array}{c}\text { Skutki } \\
\text { podatkowe } \\
\text { (razem } \\
\text { utracone } \\
\text { dochody) } \\
\text { [mln zł] }\end{array}$} & \multirow[b]{2}{*}{$\begin{array}{c}\text { Udział } \\
\text { utraconych } \\
\text { dochodów w } \\
\text { dochodach } \\
\text { z tytułu } \\
\text { podatku } \\
\text { rolnego [\%] }\end{array}$} \\
\hline & $\begin{array}{l}\text { obniżenie } \\
\text { górnych } \\
\text { stawek } \\
\text { podatkowych }\end{array}$ & $\begin{array}{c}\text { ulgi i } \\
\text { zwolnienia }\end{array}$ & $\begin{array}{c}\text { umorzenie } \\
\text { zaległości } \\
\text { podatkowych }\end{array}$ & $\begin{array}{l}\text { rozłożenie } \\
\text { na raty, } \\
\text { odroczenie } \\
\text { terminu } \\
\text { płatności }\end{array}$ & & \\
\hline $\begin{array}{l}\text { Gminy } \\
\text { ogółem, } \\
\text { w tym: }\end{array}$ & 290,08 & 3,97 & 10,92 & 3,59 & 308,6 & 19,4 \\
\hline - miejskie & 2,16 & 0,03 & 0,07 & 0,05 & 2,3 & 4,6 \\
\hline $\begin{array}{c}\text { - miejsko- } \\
\text { wiejskie }\end{array}$ & 81,25 & 1,18 & 3,08 & 1,23 & 86,7 & 16,0 \\
\hline - wiejskie & 206,66 & 2,76 & 7,77 & 2,31 & 219,5 & 21,9 \\
\hline
\end{tabular}

Źródło: opracowanie własne na podstawie danych Ministerstwa Finansów [Budżety jednostek samorządu terytorialnego. Sprawozdania budżetowe, dostęp: 10.01.2017]. 
Podatek rolny jest mało wydajnym źródłem dochodów własnych gmin. Niska efektywność podatku rolnego z punktu widzenia poziomu samodzielności finansowej gmin wiąże się z przyjęciem za podstawę opodatkowania ceny jednego produktu rolnego, którego znaczenie w produkcji rolnej w Polsce sukcesywnie się zmniejsza ${ }^{4}$. Z przeprowadzonych badań współzależności (tab. 4.) wynika, że im wyższy jest poziom samodzielności finansowej gmin wiejskich (kwantyfikowany przez poziom dochodów własnych w zł per capita), tym rola podatku rolnego jako źródła dochodów własnych jest mniejsza (związek ten, pomimo że jest istotny statystycznie, jest relatywnie słaby).

Wzrost poziomu własnego potencjału dochodowego gmin wiejskich zależy w głównej mierze od rozwoju na ich terenie innych funkcji, poza rolniczą, do tej pory charakterystycznych głównie dla obszarów miejskich, tj. przede wszystkim usługowo-rezydencjalnej. Sytuacja ta dotyczy jednak głównie gmin wiejskich położonych w bezpośrednim sąsiedztwie lub w bliskiej odległości od dużych ośrodków miejskich, które czerpią korzyści z obserwowanego od kilku lat zjawiska suburbanizacji. Gminy takie wyróżnia znacznie wyższy poziom własnego potencjału dochodowego, co wynika z wysokich wpływów do budżetu tych jednostek z dochodów podatkowych stanowiących dochód budżetu państwa (PIT i CIT). Z kolei wzrost poziomu dochodów własnych gmin wiejskich o typowo rolniczym charakterze, peryferyjnie położonych w stosunku do ośrodków miejskich możliwy może być w wyniku wprowadzenia zmian w konstrukcji podatku rolnego lub z tytułu wprowadzenia podatku dochodowego w rolnictwie. Obecna konstrukcja podatku rolnego w bardzo niewielkim stopniu powiązana jest bowiem z rzeczywistą wielkością produkcji i dochodów w rolnictwie. Relacja podatku rolnego w stosunku do produkcji globalnej i wartości dodanej brutto produkcji rolniczej jest relatywnie niska. Podatek rolny pobrany przez samorządy gminne w latach 2004-2014 stanowił co najwyżej 1,6\% całkowitej produkcji

Tabela 4. Wartości współczynników korelacji* między poziomem dochodów z podatku rolnego i jego udziałem w dochodach własnych a poziomem dochodów własnych per capita gmin wiejskich w Polsce w latach 2004-2015

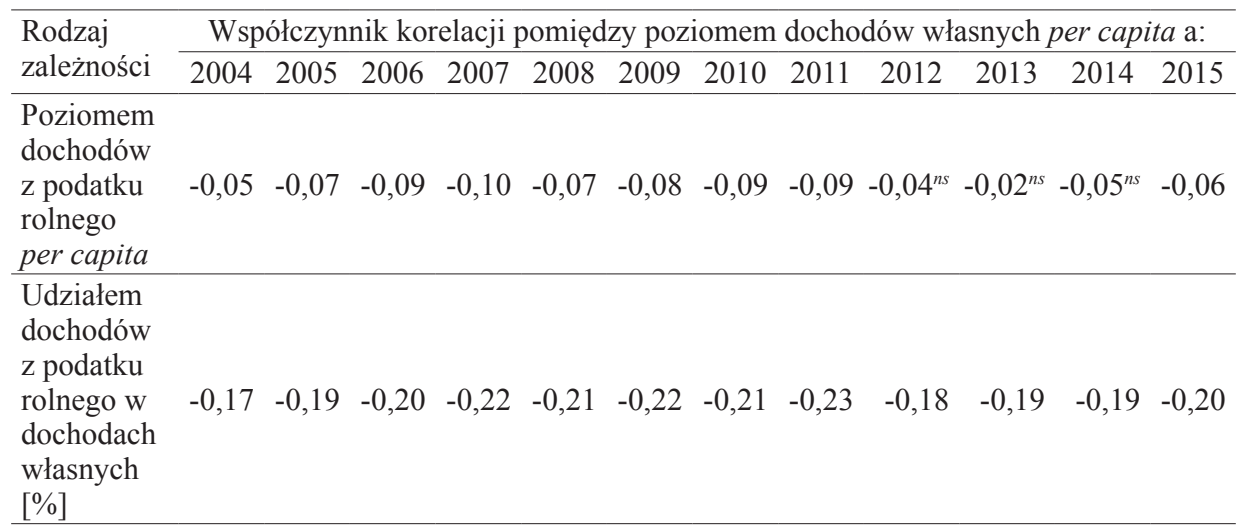

$n s-$ nieistotne statystycznie przy poziomie $\alpha=0,05$.

Źródło: opracowanie własne na podstawie danych pochodzących z GUS [Bank Danych Lokalnych, dostęp: 05.01.2017].

$4 \quad$ Według danych pochodzących z Powszechnego Spisu Rolnego przeprowadzonego w 2010 roku powierzchnia zasiewów żyta stanowiła niespełna 14\% powierzchni zasiewów ogółem [Bank Danych Lokalnych, dostęp: 10.01.2017]. 


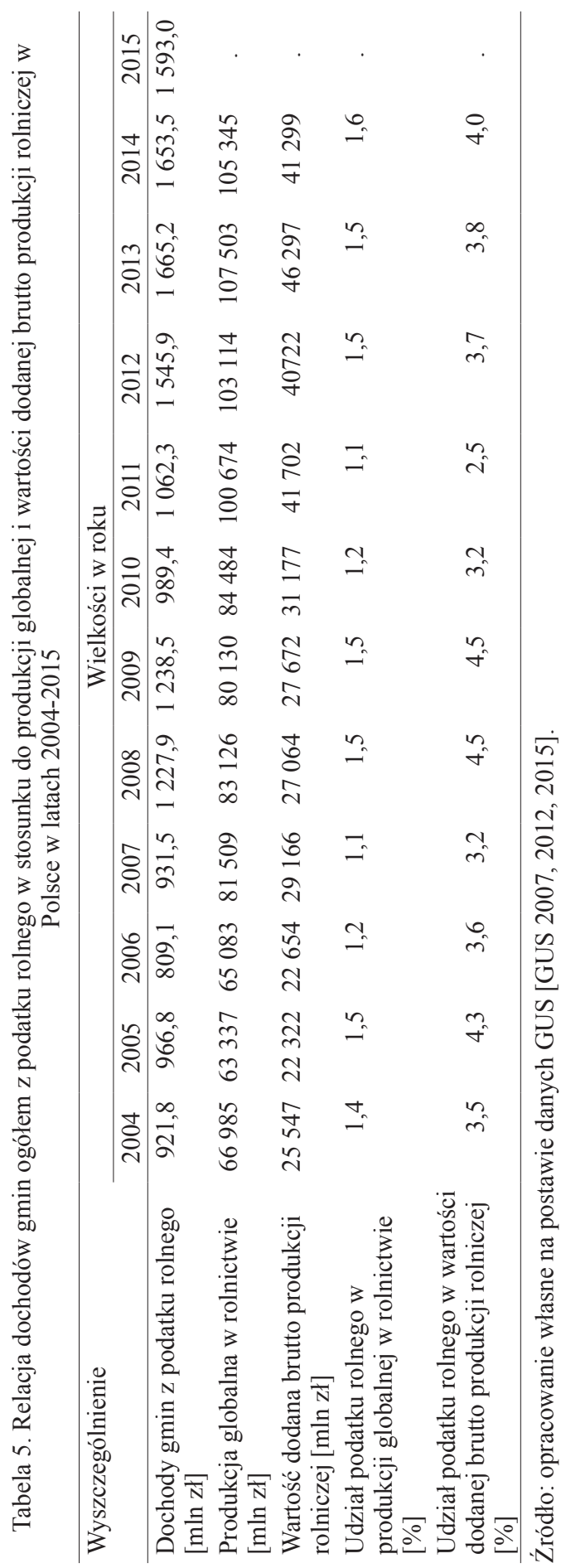

globalnej w rolnictwie oraz co najwyżej 4,5\% wartości dodanej brutto produkcji rolniczej (tab. 5.). Z badań przeprowadzonych przez M. Mądrą wynika bowiem, że obciążenie przychodów ze sprzedaży w gospodarstwach rolniczych podatkiem rolnym nie przekracza $1 \%$ we wszystkich grupach obszarowych gospodarstw rolnych, natomiast w najmniejszych gospodarstwach rolnych o sile ekonomicznej wynoszącej od 2 do 4 ESU sięga tylko $1,5 \%$ przychodów ogółem [Mądra 2009]. Obowiązujący system opodatkowania działalności rolniczej osób fizycznych jest niedostosowany do warunków gospodarki Polski. Roma Ryś-Jurek dowiodła, że podatki rolne płacone przez polskie gospodarstwa rolne kształtują się na poziomie znacznie niższym w relacji do średniej ich wysokości w krajach UE [Ryś-Jurek 2014]. Głównym problemem jest praktycznie nieistniejący w rolnictwie podatek dochodowy, który według M. Chmielewskiej rzutuje na niesprawiedliwość społeczną i niewydolność całego systemu [Chmielewska 2009].

\section{PODSUMOWANIE}

Podatek rolny największą rolę odgrywa w gospodarce budżetowej gmin wiejskich, w których w 2015 roku dochody z jego tytułu stanowiły ponad $16 \%$ ogółu dochodów z podatków lokalnych, podczas gdy $9,6 \% \mathrm{w}$ gminach miejsko-wiejskich i 0,4\% w gminach miejskich. Rola fiskalna podatku rolnego w gminach wiejskich jest coraz mniejsza. Świadczy o tym fakt, że w 2015 roku w stosunku do 2004 roku relacja dochodów tych podmiotów $\mathrm{z}$ podatku rolnego do dochodów własnych oraz dochodów 
z podatków lokalnych uległa zmniejszeniu. Wpływ na tę sytuację miał rozwój funkcji rezydencjalno-usługowej na terenie wielu gmin wiejskich położonych wokół większych ośrodków miejskich jako efektu zjawiska suburbanizacji, a co za tym, idzie szybkiego wzrostu poziomu dochodów własnych gmin z podatków dochodowych od osób fizycznych i prawnych.

W warunkach integracji europejskiej, pomimo wzrostu dochodowości w polskim rolnictwie nadal znaczna część gmin wiejskich stosuje niższe stawki podatkowe, które skutkują zmniejszeniem poziomu uzyskiwanych dochodów własnych. Utracone dochody z podatku rolnego w wyniku stosowania władztwa podatkowego w 2015 roku stanowiły w gminach wiejskich ponad jedną piątą ogółu dochodów z podatku rolnego.

Niski poziom własnego potencjału dochodowego gmin wiejskich wynika z nieefektywnego, z punktu widzenia samodzielności finansowej JST, systemu opodatkowania rolnictwa podatkiem rolnym, którego konstrukcja w bardzo niewielkim stopniu powiązana jest z rzeczywistą wielkością produkcji i dochodów w rolnictwie. Uzależnienie wysokości podatku rolnego od liczby hektarów przeliczeniowych oraz wybór naturalnego miernika do jego kalkulacji to przestarzały mechanizm. Wpływa to na relatywnie niską funkcję fiskalną tego podatku. Zasadne byłoby dostosowanie podatku rolnego do szerszego systemu podatków majątkowych i dochodowych oraz do stanu rozwoju polskiego rolnictwa. Należy w związku z tym oczekiwać działań zmierzających do wypracowania rozwiązań w zakresie zmian podatku rolnego oraz stopniowego wprowadzenia podatków dochodowych w rolnictwie.

\section{LITERATURA}

Bank Danych Lokalnych, GUS, Warszawa, www.stat.gov.p1/BDL.

Chmielewska Marzena, 2009: Podatek rolny $w$ dochodach budżetowych gmin, ,Zeszyty Naukowe SGGW w Warszawie. Ekonomika i Organizacja Gospodarki Żywnościowej”, nr 77, s. 187-197.

Filipiak Beata, 2016: Skutki udzielania ulg, umorzeń $i$ zwolnień przez organy podatkowe gmin, „Finanse, Rynki Finansowe, Ubezpieczenia”, 5 (83), s. 177-187.

Goraj Lech, Jarosław Neneman, Marek Zagórski, 2014: Uwarunkowania i konsekwencje opodatkowania rolnictwa w Polsce, Forum Inicjatyw Rozwojowych (dostęp: http://www.efrwp.pl).

GUS. Roczne wskaźniki makroekonomiczne, Warszawa, http://stat.gov.pl/wskazniki-makroekonomiczne, dostęp: 05.01.2017.

GUS. 2007: Rocznik statystyczny rolnictwa i obszarów wiejskich 2007, Warszawa.

GUS. 2012: Rocznik statystyczny rolnictwa 2012, Warszawa.

GUS. 2015: Rocznik statystyczny rolnictwa 2015, Warszawa.

Jastrzębska Maria, 2012: Finanse jednostek samorządu terytorialnego, Wolters Kluwer SA, Warszawa.

Kiełczyńska-Kiełbasa Ewa, 2015: Rozliczanie podatków i innych danin publicznych, WSiP, Warszawa.

Konstytucja Rzeczpospolitej Polskiej z dnia 2 kwietnia 1997 roku, Dz.U. 1997.78.483 z późn. zm.

Kozera Agnieszka, Feliks Wysocki, 2015: Typ funkcjonalny a samodzielność finansowa gmin wiejskich województwa wielkopolskiego, „Roczniki Naukowe Stowarzyszenia Ekonomistów Rolnictwa i Agrobiznesu", t. XVII, z. 6, s. 133-139.

Lubińska Teresa, Sławomir Franek, Marcin Będzieszak, 2007: Potencjał dochodowy samorzadu w Polsce na tle zmian ustawy o dochodach jednostek samorzadu terytorialnego, Difin, Warszawa.

Mądra Magdalena, 2009: Obciażenie podatkiem rolnym indywidualnych gospodarstw rolnych, „Zeszyty Naukowe SGGW w Warszawie, Ekonomika i Organizacja Gospodarki Żywnościowej”, 76, s. $175-186$.

MF (Ministerstwo Finansów). Budżety jednostek samorządu terytorialnego - Sprawozdania budżetowe, http://www.mf.gov.pl/ministerstwo-finansow/dzialalnosc/finanse-publiczne/budzety-jednostek-samorzadu-terytorialnego/sprawozdania-budzetowe, dostęp: 10.01.2017. 
Przygodzka Renata, 2014a: Władztwo podatkowe a stabilność finansowa gmin, „Nierówności Społeczne a Wzrost Gospodarczy", 40, s. 334-343.

Przygodzka Renata, 2014b: Źródła finansowania gmin wiejskich w Polsce, „Roczniki Naukowe Stowarzyszenia Ekonomistów Rolnictwa i Agrobiznesu", t. XVI, z. 6, s. 409-414.

Przygodzka Renata, 2016: System podatkowy i zabezpieczenie społeczne wsi, [w] Polska wieś 2016 - Raport o stanie wsi, red. Jerzy Wilkin, Iwona Nurzyńska, Fundacja na rzecz Rozwoju Polskiego Rolnictwa, Wydawnictwo Scholar, Warszawa.

Ryś-Jurek Roma, 2014: Opodatkowanie gospodarstw rolnych w Unii Europejskiej w latach 20042011, „Polityki Europejskie, Finanse i Marketing”, 16 (60), s. 204-216.

Ustawa z dnia 15 listopada 1984 r. o podatku rolnym, Dz.U.2016, poz. 617.

Agnieszka Kozera

THE AGRICULTURAL TAX AS A SOURCE OF OWN INCOME OF RURAL COMMUNES IN POLAND

\section{Summary}

The main aim of the article was to show the importance of the agricultural tax as a source of own income of rural communes in Poland in 2004-2015. In order to determine the fiscal importance of the tax, the amount and share of income from the agricultural tax in the own income of rural communes were compared to other types of communes. In addition, the amount of income lost due to the agricultural tax was analyzed. The study showed that the agricultural tax as a source of own income plays the most important role in the budgets of rural communes, although the fiscal role of the tax in these local government sector entities is getting smaller. The agricultural taxation system, which is ineffective from the point of view of communes' financial self-sufficiency and the construction of which is to a very limited extent related to the real amount of production and income in agriculture, is reflected in the low level of own income potential of rural communes.

Adres do korespondencji:

Dr Agnieszka Kozera

Uniwersytet Przyrodniczy w Poznaniu

Wydział Ekonomiczno-Społeczny, Katedra Finansów i Rachunkowości ul. Wojska Polskiego 28, 60-637 Poznań e-mail: akozera@up.poznan.pl 